\title{
Parasitism rates of Lipoptena guimaraesi and a new record of Lipoptena mazamae on Ozotoceros bezoarticus from the Central Pantanal wetlands in Brazil
}

\author{
Índices parasitológicos de Lipoptena guimaraesi e novo registro de Lipoptena mazamae \\ sobre Ozotoceros bezoarticus no Pantanal central, Brasil \\ Gustavo Graciolli ${ }^{*}$; Carlos André Zucco²; Paulo Henrique Duarte Cançado ${ }^{3}$; Guilherme Mourão ${ }^{4}$ \\ ${ }^{1}$ Centro de Ciências Biológicas e da Saúde, Universidade Federal de Mato Grosso do Sul - UFMS \\ ${ }^{2}$ Laboratório de Ecologia e Conservação de Populaçóes, Instituto de Biologia, Universidade Federal do Rio de Janeiro - UFRJ \\ ${ }^{3}$ Embrapa Gado de Corte, Empresa Brasileira de Pesquisa Agropecuária - EMBRAPA \\ ${ }^{4}$ Centro de Pesquisa Agropecuária do Pantanal, Empresa Brasileira de Pesquisa Agropecuária - EMBRAPA
}

Received September 3, 2010

Accepted December 22, 2010

\begin{abstract}
From May to October of 2006 we collected 143 louse flies of the genus Lipoptena on the body surface of 16 pampas deer Ozotocerus bezoarticus captured in four farms from the central area of the Brazilian Pantanal wetlands. We also examined 172 cattle individuals and none of them had louse flies. Most of the parasites identified were Lipoptena guimaraesi but one specimen of $L$. mazamae was also found, representing a new host record for this ked fly. The prevalence of L. guimaraesi was $93.8 \%$, the mean intensity of infestation was 9.5 , and the index of discrepancy was 0.444 .
\end{abstract}

Keywords: Diptera, Hippoboscidae, Lipoptena spp., Ozotocerus bezoarticus.

\begin{abstract}
Resumo
De Maio a Outubro de 2006, 143 hipoboscídeos do gênero Lipoptena foram coletados sobre a superfície corporal de 16 veados-campeiros Ozotocerus bezoarticus capturados em quatro fazendas localizadas na área central do Pantanal brasileiro. Também foram examinados 172 bovinos na mesma área, sobre os quais não foram encontrados hipoboscídeos. Muitos dos parasitos foram identificados como Lipoptena guimaraesi apesar de um indivíduo de L. mazamae, registrado pela primeira vez sobre veado-campeiro. A prevalência de L. guimaraesi foi de 93,8\%, a intensidade média de infestação foi de 9,5 e o índice de discrepância foi de 0,444.
\end{abstract}

Palavras-chave: Diptera, Hippoboscidae, Lipoptena spp., Ozotocerus bezoarticus.

The subfamily Lipopteninae (Diptera, Hippoboscidae) comprises three genus of blood feeding ked flies which are mainly ectoparasites of Artiodactyla mammals: Lipoptena, Melophagus, and Neolipoptena (MAA, 1969). These are louselike larviparous insects, dorsoventrally flattened with robust legs, and mouthparts directed forward (LLOYD, 2009). Lipoptena and Neolipoptena parturition occurs before puparian formation and development is into winged imagines ("volant individuals") that lose their wings right after reaching the host (BEQUAERT, 1953), while the more specialized Melophagus do not have functional wings in any stage of life cycle. Most of the published studies about the distribution

\footnotetext{
*Corresponding author: Gustavo Graciolli

Centro de Ciências Biológicas e da Saúde,

Universidade Federal de Mato Grosso do Sul - UFMS,

CP 549, CEP 79070-900, Campo Grande - MS, Brazil;

e-mail: ggraciolli@yahoo.com.br
}

of Lipoptena and Neolipoptena species on host populations with descriptive parasitism indexes (prevalence and abundance/intensity) are available only for Neartic Region (SAMUEL; TRAINER, 1972; DAVIS, 1973; EADS; CAMPOS, 1984; FORRESTER et al., 1996). In the New World, where four species of Lipoptena are known to occur (PETERSON; MAA, 1970), data is still scarce and focused on L. cervi, L. depressa and L. mazamae that parasite the North American deer Odocoileus spp., Rangifer tarandus, Cervus spp., and Capreolus capreolus. Although Lipopteninae are often host specific to Bovidae and Cervidae species (MAA, 1969), incidental infestations of humans have been documented (IVANOV, 1975).

Until recently, deer keds have not been clearly associated to transmission of any infection agent either to its wild host or cattle and humans. However, Dehio et al. (2004), Halos et al. (2004) and Reeves et al. (2006) provided evidence that deer keds (L. cervi 
and L. mazamae) are natural reservoirs for Bartonella spp. and may act as vectors for transmission of this bacterium within ruminant population and potentially to humans.

Lipoptena guimaraesi was described by Bequaert (1957) based on specimens collected from the South American pampas deer Ozotoceros bezoarticus in the States of Mato Grosso and Goiás, central-western Brazil. The holotype and most of the paratypes are deposited at the Zoology Museum of the Universidade de São Paulo. Recently, there have been new geographic records in the States of Tocantins, Central-Western Brazil (DESIDERIO et al., 1999), and Paraná, southern Brazil (GRACIOLLI; CARVALHO, 2003), and in Uruguay (JACKSON, 1987). However, there is still no information about infestation rates and prevalence.

In this paper we report the infestation and infrapopulation parameters of L. guimaraesi on $O$. bezoarticus in the Central Pantanal wetlands in Brazil, and this is also the first record of L. mazamae on pampas deer.

From May to October of 2006, we captured 16 pampas deer at four cattle ranches in the Nhecolândia region of Pantanal wetlands, State of Mato Grosso do Sul. The region is characterized by close contact between cattle and wildlife. Pampas deer predominantly live in open habitats and often found feeding together with cattle. We also examined 172 cattle individuals from one of these ranches.

The deer were captured by darting from cars, all-terrain vehicles (ATVs), or on foot using a Distinject ${ }^{\oplus}$ (Zurich, Switzerland) model 35 dart gun. The animals were chemically restrained as described by Piovezan et al. (2006). All proceedings were authorized by the Brazilian Federal Environment Agency (IBAMA) under licenses 26/2005 and 032/2005 (protocols no. 02014.001890/2005-66 and no. 02014.002008/05-00) and followed the Guidelines for Capture, Handling and Care of Mammals as approved by the American Society of Mammalogists (ANIMAL CARE AND USE COMMITTEE, 1998).

We carefully examined the deer for ectoparasites over 5 minutes during handling procedures. If infestation was high, parasite collection was continued until we could not find more individuals. Lipoptena were collected with metal clamps and stored in $70 \%$ ethanol, labeled according to host individual. Cattle were brought to the management's corral and held individually in a squeeze gate for full body examination for ectoparasites.

In 70\% ethanol vouchers (one couple) were deposited at the Acariology Collection of the Universidade Federal Rural do Rio de Janeiro, Seropédica, and the remaining specimens (deposited number INS100 to INS117) were deposited at the Zoological Reference Collection of the Universidade Federal do Mato Grosso do Sul, Campo Grande.

The infrapopulation was described in terms of prevalence (number of infested hosts)/(number of examined hosts) and mean intensity of infestation (number of ectoparasites)/(number of infested hosts), with their related $95 \%$ confidence intervals (BUSH et al., 1997). Aggregation level of deer ked was measured with the index of discrepancy (POULIN, 1993). Quantitative Parasitology 3.0 software (RÓZSA et al., 2000) was used to calculate parasitological and discrepancy indexes.

We collected 66 males and 76 females of L. guimaraesi (Figure 1) and one female of $L$. mazamae on 16 O. bezoarticus. The keds were always found on the ventral area and legs of hosts, especially near

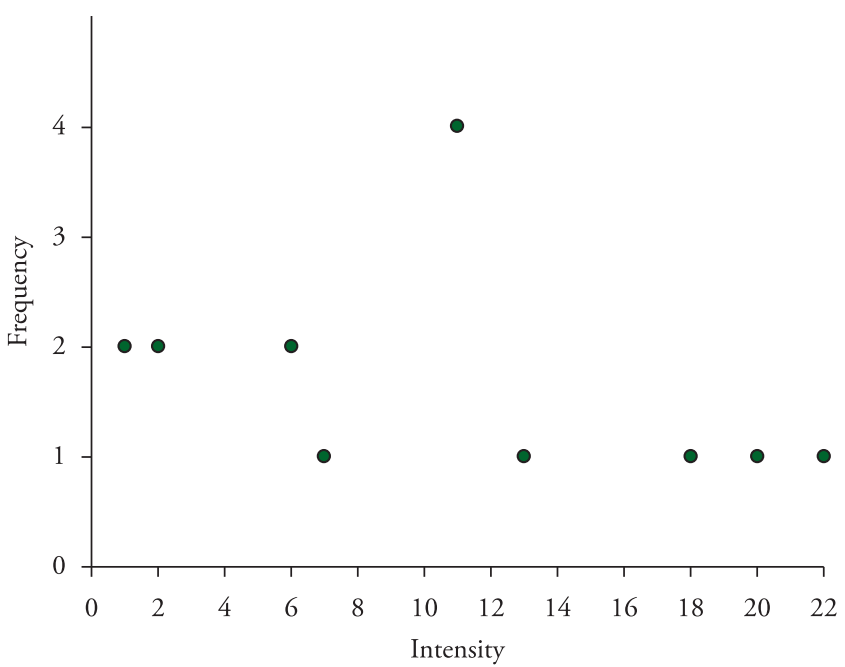

Figure 1. Intensity of infestation of Lipoptena guimaraesi on Ozotoceros bezoarticus in Nhumirim ranch, Mato Grosso do Sul, Brazil, 2006.

the genitals and anus. The fur of these body parts is white and softer than dorsal pelage. No remarkable skin or fur damage to the infested deer could be observed. The index of discrepancy was 0.444 , suggesting a non-aggregate distribution of $L$. guimaraesi on O. bezoarticus. The prevalence was $93.8 \%$ (69.76 to $99.85 \%)$ and the mean intensity of infestation 9.5 (6.27 to 12.93). Among the 142 specimens of L. guimaraesi, six (three males and three females) volant individuals were collected in deer captured on September and October, indicating that volant emergency occurs at the late dry season in Pantanal. Fifteen female specimens were pregnant with mature larvae.

No keds were found in the cattle examined. The study sites shelter vigorous populations of pampas deer (TOMÁS et al., 2001), red brocket deer (Mazama americana) and gray brocket deer (Mazama gouazoubira). The latter two species have been recorded as hosts of Lipoptena mazamae in different regions of Central and South America (BEQUAERT, 1957). Hence, the fact that we found just one individual of $L$. mazamae parasitizing pampas deer confirms the occurrence of L. mazamae in the Brazilian Pantanal, but suggests that it can only incidentally parasite pampas deer. Though the high prevalence of L. guimaraesi on pampas deer confirms that the parasitism is recurrent, a host specific relation cannot be confirmed since the presence of this parasite was evaluated in brocket deer from Pantanal wetlands or adjacent ecoregions.

Even though deer keds were neither found in cattle nor reported in any domestic dog or human from the research station at Nhumirim ranch, there are still reasons for caution. As bloodsucking parasites that can potentially affect different species, including domestic and wild, its role as vectors of disease agents should be investigated.

The Pantanal region is characterized by the sympatry of wildlife species, cattle and humans, and can pose a high risk to public health and the economy due to disease outbreaks. The role of Lipoptena species as vectors of Bartonella spp. (REEVES et al., 1996; 
HALOS et al., 2004) and anaplasmosis in cattle (DRUMMOND, 1966) is an example of a known risk. Besides, louse flies are still poorly known in Neotropics, thus their relation with disease transmission is certainly underestimated.

Further studies on pampas deer, especially those that require to be captured, should focus on investigating the presence of Bartonella strains on both deer keds and their hosts, and further studies on brocket deer species should also investigate parasite infection by $L$. mazamae.

\section{Acknowledgements}

This study was supported by the Conselho Nacional de Desenvolvimento Científico e Tecnológico (Project PELD/CNPq No. 520056/98-1). C. A. Zucco was supported by a grant from the Coordenaçáo de Aperfeiçoamento de Pessoal de Ensino Superior (CAPES). Cesar Zucco greatly helped reviewing the language.

\section{References}

ANIMAL CARE AND USE COMMITTEE. Guidelines for the captures, handling, and care of mammals as approved by the American Society of Mammalogists. Journal of Mammalogy, v. 79, n. 4, p. 1416-1431, 1998. http://dx.doi.org/10.2307/1383033

BEQUAERT, J. The Hippoboscidae or louse-flies (Diptera) of mammals and birds. Part. I. Structure, physiology and natural history. Entomologica Americana, New Series, v. 32, p. 233-416, 1953.

BEQUAERT, J. The Hippoboscidae or louse-flies (Diptera) of mammals and birds. Part II. Taxonomy, evolution and revision of American genera and species. Entomologica Americana, New Series, v. 36, p. 417-611, 1957.

BUSH, A. O. et al. Parasitology meets Ecology on its own terms: Margolis et al. revisited. Journal of Parasitology, v. 83, n. 4, p. 575-583, 1997. PMid:9267395. http://dx.doi.org/10.2307/3284227

DAVIS, J. W. Deer ked infestation on white-tailed deer in East Texas. Journal of Wildlife Management, v. 37, n. 2, p. 183-186, 1973. http:// dx.doi.org/10.2307/3798902

DEHIO, C.; SAUDER, U.; HIESTAND, R. Isolation of Bartonella schoenbuchensis from Lipoptena cervi, a blood-sucking arthropod causing deer ked dermatitis. Journal of Clinical Microbiology, v. 42, n. 11, p. 5320-5323, 2004. PMid:15528732. PMCid:525279. http://dx.doi. org/10.1128/JCM.42.11.5320-5323.2004

DESIDERIO, M. H. G. et al. Lipoptena (Lipoptenella) guimaraesi Bequaert, 1954 (sic) (Diptera: Hippoboscidae) em veado campeiro (Ozotocerus bezoarticus Ribeiro, 1919) (sic), em Tocantins, Brasil. Entomología y Vectores, v. 6, p. 204-210, 1999.

DRUMMOND, R. O. Lipoptena mazamae Rondani (Diptera: Hippoboscidae), a louse fly of deer, on cattle in southwestern Texas. Journal of Parasitology, v. 52, n. 4, p. 825, 1966. PMid:5969131. http://dx.doi.org/10.2307/3276467
EADS, R. B.; CAMPOS, E. G. Notes on the deer keds Neolipoptena ferrisi and Lipoptena depressa (Diptera: Hippoboscidae) from Colorado, USA. Journal of Medical Entomology, v. 21, n. 2, p. 245, 1984.

FORRESTER, D. J. et al. Ectoparasites (Acari, Mallophaga, Anoplura, Diptera) of white-tailed deer, Odocoileus virginianus, from Southern Florida. Journal of Medical Entomology, v. 33, n. 1, p. 96-101, 1996. PMid:8906911.

GRACIOLLI, G.; CARVALHO, C. J. B. Hippoboscidae (Diptera, Hippoboscoidea) no estado do Paraná, Brasil: chaves de identificação, hospedeiros e distribuição geográfica. Revista Brasileira de Zoologia, v. 20, n. 4, p. 667-674, 2003. http://dx.doi.org/10.1590/S010181752003000400019

HALOS, L. et al. Role of Hippoboscidae flies as potential vectors of Bartonella spp. infecting wild and domestic ruminants. Applied and Environmental Microbiology, v. 70, n. 10, p. 6302-6305, 2004. PMid:15466580. PMCid:522062. http://dx.doi.org/10.1128/ AEM.70.10.6302-6305.2004

IVANOV, V. I. Anthropophilia of the deer blood sucker Lipoptena cervi L. (Diptera, Hippoboscidae). Medicinskaja parazitologija i parazitarnye bolezni (Mosk), v. 44, n. 4, p. 491-495, 1975.

JACKSON, J. E. Ozotoceros bezoarticus. Mammalian species, v. 295, p. 1-5, 1987. http://dx.doi.org/10.2307/3504043

LLOYD, J. E. Louse flies, keds, and related flies (Hippoboscoidea). In: MULLEN, G.; DURDEN, L. (Ed.). Medical and Veterinary Entomology. 2. ed. Burlington: Academic Press, 2009. p. 331-344.

MAA, T. C. A revised checklist and concise host index of Hippoboscidae (Diptera). Pacific Insects Monograph, v. 20, p. 261-299, 1969.

PETERSON, B. V.; MAA, T. C. A new Lipoptena from Chile, with a key to the New World species (Diptera: Hippoboscidae). Canadian Entomologist, v. 102, n. 9, p. 1117-1122, 1970. http://dx.doi. org/10.4039/Ent1021117-9

PIOVEZAN, U.; ZUCCO, C. A.; ROCHA, F. L. Uso de dardos anestésicos para a captura de veados campeiros (Ozotoceros bezoarticus) no Pantanal. Boletim de Pesquisa e Desenvolvimento / Embrapa Pantanal, v. 71, p. 1-22, 2006.

POULIN, R. The disparity between observed and uniform distributions - a new look at parasite aggregation. International Journal for Parasitology, v. 23, n. 7, p. 937-944, 1993. http://dx.doi.org/10.1016/00207519(93)90060-C

REEVES, W. K. et al. Bartonella spp. in deer keds, Lipoptena mazamae (Diptera, Hippoboscidae), from Georgia and South Carolina, USA. Journal of Wildlife Disease, v. 42, n. 2, p. 391-396, 2006. PMid:16870863.

RÓZSA, L.; REICZIGEL, J.; MAJOROS, G. Quantifying parasites in samples of hosts. Journal of Parasitology, v. 86, n. 2, p. 228-232, 2000.

SAMUEL, W. M.; TRAINER, D. O. Lipoptena mazamae Rondani, 1878 (Diptera: Hippoboscidae) on white tailed deer in Southern Texas. Journal of Medical Entomology, v. 9, n. 1, p. 104-106, 1972. PMid:5019196.

TOMAS, W. M. et al. A survey of a pampas deer, Ozotoceros bezoarticus leucogaster (Arctiodactyla, Cervidae), population in the Pantanal wetland, Brazil, using the distance sampling technique. Animal Biodiversity and Conservation, v. 24, n. 1, p. 101-106, 2001. 